\title{
Macroeconomic Policies for Recovery in Europe and in Italy
}

\author{
Enrico Marelli*
}

\begin{abstract}
The Covid-19 pandemic has caused an unprecedented shock; the national and EU responses have been swifter in Europe, if compared with the "too little too late" approach (followed after the sovereign debt crisis). As for macroeconomic policies, they are necessary not only on the monetary side, but also from the EU budget, also with the adoption of some innovative instruments: the Next Generation EU "recovery and resilience" fund can be an important turning point. This facility is fundamental for a country like Italy, in order to convert its long-run decline and to solve its enduring structural problems. However, macroeconomic policies should be accompanied by appropriate industrial and regional policies, also focusing on wellselected investment projects. The final aim is to achieve an economic growth fully sustainable, on economic, environmental and social grounds.
\end{abstract}

Keywords: Pandemic Crisis; Macroeconomic Policies; Recovery; Sustainable Growth; European Economy; Italian Economy; Global Markets

\section{The Pandemic: An Unprecedented Shock}

The pandemic, caused by Covid-19, is hitting the world economy in an unprecedented way ${ }^{1}$. The virus caused in the world millions of infected people and hundreds of thousands of deceased. Started in China in January 2020, the pandemic arrived to Europe - Italy was the first country in the continent to be attacked ${ }^{2}$ - and soon propagated to the whole world. There has already been a lively discussion on how the national health systems reacted to the health emergency. For sure, in many countries there have been unpreparedness, delays, and conflicting views on how to deal with the pandemic: initially among the virologists themselves, later between policymakers at different levels (for instance in Italy between national and regional governments). In general, European and Western countries had a less prompt and effective response compared to Far Eastern countries, such as South Korea and Japan (Valli, 2020). Of course, the reduction in public expenditures for the health systems in the last decade - at least in relative terms - suffered by many European countries, including Italy, also because of the "austerity approach" consequent to the Eurozone

*Full Professor of Economic Policy, University of Brescia (enrico.marelli@unibs.it)

Edited by: Niccolò Cusano University

ISSN: $1593-0319$

Marelli, E. (2021). Macroeconomic Policies for Recovery in Europe and in Italy. Symphonya. Emerging Issues in Management (symphonya.unicusano.it), (1), 64-75.

https://dx.doi.org/10.4468/2021.1.07marelli 
crisis (Marelli \& Signorelli, 2017), has been one of the causes of the mentioned unpreparedness.

The lockdown measures adopted in several countries led to a more or less extended and prolonged suspension of production in many industries and services. This suspension added to the sudden interruption of international supply chains. Therefore, it is clear that the initial shock has been a supply-side shock (Baldwin \& Weder di Mauro, 2020). However, soon the shock became a demand-side shock as well: the falling incomes of workers in the suspended activities (unemployment benefits and wage integration measures, even when available, were not sufficient to guarantee pre-crisis wages and salaries) caused an abrupt fall in consumption. In some sectors, consumption has not recovered even at the end of the emergency's peak, because of fears of contagion (e.g. in public transport, hotels, restaurants, tourism in general). The generalised uncertainty is also depressing consumption. Private investment collapsed despite the abundant liquidity created by central banks (see below). Exports have been badly affected since most countries in the world are experiencing similar downfalls.

Therefore, the current recession is surely deeper than the so-called "Great Recession" of 2009, following the 2007-08 financial crisis. Differently from that period (when many imbalances accrued in the private sectors, because of high debts and financial vulnerability), this new recession is exogenous. Moreover, it is symmetric because a common enemy - the virus - hit almost all countries; again differently from the 2011-12 Eurozone's crisis, where the peripheral countries suffered more because of their financial situation (sovereign debt sustainability). This point is important to consider also in view of the possible policy reactions while in 2011-12 specific measures such as the "save-State" funds (including the ESM) were created to tackle the condition of specific countries, now a common response, at least at the European level, is fully justified.

Although symmetric, the current shock obviously has asymmetric effects, not only between countries but also across different productive sectors. As already mentioned, the largest immediate impact has been found in sectors such as transports, hotels and restaurants, cultural and recreation activities, personal services, commerce. The macroeconomic impact is, in any case, extreme. For the world economy, the projections prepared by international institutions are sharp, although in the context of a great uncertainty.

IMF (2020) forecasts a fall of GDP in 2020 equal to $4.9 \%$ in the world, but up to $8 \%$ in the advanced economies. OECD (2020) forecasts a $6 \%$ decline in the world economy and much greater in Europe.

If we now focus on Italy, forecasts of the GDP fall in 2020 range from $8 \%$ by the Government (MEF, 2020) ${ }^{3}, 8.3 \%$ by ISTAT (National Statistical Office), $12.8 \%$ by the IMF, $11.2 \%$ by the EU Commission (Summer forecast), $11.3 \%$ by OECD. For 2021 a partial recovery is foreseen, but on average corresponding to just half of this year's fall: an increase of GDP equal to $4.6 \%$ is forecasted by ISTAT, $4.7 \%$ by the Government, $6.3 \%$ by the IMF, $6.1 \%$ by the EU Commission and $7.7 \%$ by OECD. Notice that OECD presented also a bad scenario, characterised by a return of contagion in autumn 2020: in that case, the GDP reduction in Italy this year would be greater $(-14 \%)$ and the recovery next year smaller $(+5.3 \%)$. Also Bank of Italy (2020) forecasts, in the basic scenario for this year, a fall of $9 \%$, but increased to $13 \%$ in a bad scenario (based on "more negative, but not extreme" assumptions). 


\section{Macroeconomic Policies in Europe}

To face so a huge shock, what has been the reaction in Europe? Our analysis will refer to the macroeconomic policies, not to the policies directed to the health system or to the industry-specific policies pointed to the sectors specifically hurt by the shock.

In general, fiscal policies adopted by individual countries have reacted swiftly and generously. The initial measures undertaken by the Governments (as declared in the Stability Programs presented to the EU Commission in April 2020) range from more than $4 \%$ of GDP in Germany and Italy, too little above 3\% in Spain (and also in the euro area on average), to almost 3\% in the Netherlands, to about 2\% in France (Bank of Italy, 2020). Such measures, in addition to exceptional expenses for the health systems, include unemployment benefits and income support measures, liquidity provision for firms and households (including cancellation or postponement of tax obligations), state warranties on bank loans to firms.

At the EU level, the swiftest response was undertaken, in the euro area, by the ECB. After some initial uncertainties, EU March it decided the extension of the $\mathrm{QE}^{4}$.

$\square$ In particular, the Asset Purchase Programme (APP) increased by 360 billion euro up to the end of 2020. The new Pandemic Emergency Purchase Programme (PEPP) was also decided in March, initially 750 billion euro, augmented with additional 600 billion euro decided in June and continuing until June 2021 (reinvestments will be possible until 2022). The purchases of public bonds can temporarily deviate from a strict proportionality with respect to the "capital key" (i.e. the individual country's weight in the ECB capital). However, the deviations are temporary and insufficient to reduce in a significant way the spreads between interest rates on bonds of individual countries and those on German bonds (Accademia Nazionale dei Lincei, 2020), which causes not only a burden on the public budgets of peripheral states but also a cost for private banks and firms, undermining their competitiveness.

Regarding monetary policy, although on one side there are some doubts that the abundant liquidity may cause speculative bubbles and instability in financial markets, on the other side some economists demand for a more active and extraordinary policy by the ECB. For example through an explicit monetary financing of public deficits, or the purchase of bonds also in the primary market (De Grauwe, 2020), or an indirect purchase by means of a Special Purpose Vehicle (Amato et al., 2020; BottaCaverzasi-Russo, 2020); or specific credit lines to support firms (Bénassy-Quéré et al., 2020), or even the "helicopter money" (Galì, 2020) .

Are such proposals feasible? In the short run, the answer seems negative, in particular because of the statutory limits of the ECB itself. In contrast to these rigidities, the Fed in the US reduced to zero the interest rate and flooded of liquidity. In August it anticipated a re-orientation of its monetary strategy by better defining the goal of full employment and stating that the $2 \%$ inflation target should be considered as an average over many years (thus allowing in some periods an inflation 
rate higher than 2\%). All this implies a very accommodative monetary policy for many years to come.

In Europe, monetary, fiscal and structural policies should be performed in a coordinated way (Panetta, 2021). In any case, now more space of manoeuvre can be gained at the fiscal level, by employing the EU budget or new instruments that are going to be introduced. Several theoretical proposals have been made. For instance, a common issue of public debt of very long maturity (50 or 100 years or even perpetual) or the release of a common debt backed by the introduction of new "European taxes"; in addition to the continuous propositions of various types of Eurobonds. However, the current request is different from the discussion of about a decade ago (at the time of the sovereign debt crisis). It does not share the existing public debts (each country will remain fully responsible for its previous sovereign debt), but it just issues a new common debt financing new expenditures related to the health systems, the Green Deal, the digital economy, etc. Many appeals in this direction have been published since March $2020^{6}$.

Pressed by the public opinion, the suggestions of experts, the insistence of some Governments, the EU Commission has reacted more promptly, at least if compared with the "too little too late" approach followed the sovereign debt crisis (Marelli \& Signorelli, 2017). Said that, the dimension of the economic disaster indeed required a stronger response.

$\square$ The key measures have been the following. First of all, the suspension of the rules of the Stability and Growth Pact and the Fiscal Compact, about the deficit/GDP and debt/GDP ratios. Secondarily, a new line of credit of the European Investment Bank to sustain small and medium sized firms (worth 200 bn. euros). Third, the plan SURE (Support to mitigate Unemployment Risks in an Emergency) to finance the national agencies providing income support, such as the CIG in Italy (100 bn. euros). Fourth, the new credit line of the ESM (European Stabilization Mechanism), with the only conditionality to use the loans for expenditures directly or indirectly related to the pandemic emergency: 240 bn. euros (36 bn. for Italy, equivalent to $2 \%$ of GDP).

Finally, the much debated instrument proposed by the EU Commission is the "Next Generation EU", a fund worth 750 bn. euros, of which 500 bn. consisting (in the initial proposal) in transfers (grants) from the EU budget - financed also by the issuance of a common debt - and the remaining amount in long term loans. It has not been easy to reach an agreement within the European Council ${ }^{7}$. The final compromise, reached within the Council on July 21 (under the German semi-annual presidency of the Council), envisages a different mix: 390 bn. of grants and $360 \mathrm{bn}$. of loans. However, the resources will be available to individual countries only from mid-2021 and a complex procedure, involving both the Commission and the Council, is foreseen for the governance of the fund.

The simplest alternative solution would have been a sharp increase of the slim EU budget (only 1\% of GDP so far). A greater budget for the EU and a specific budget for the Eurozone would be important not only to face economic shocks or for business cycle stabilisation, but also to favour long-run economic convergence 
among European economies. Notice that policymakers, when launching previous plans such as the Lisbon Agenda and the Europe 2020 strategy, were conscious of the large imbalances existing between European countries and regions. The problem is that with limited resources the cohesion and convergence goals are almost wishful thinking: all structural funds devoted to cohesion policy account for less than $0.5 \%$ of EU's GDP. It is not necessary that the EU becomes a "transfer union" (an outcome obviously refuted by many core countries); it would be sufficient a direct involvement of the EU institutions in structural projects, e.g. to stimulate infrastructures, human capital, R\&D, innovations.

In any case, considering the political infeasibility of a sharp increase in the EU budget, the proposed Recovery Fund can be considered as a first step toward a "fiscal union", i.e. an example of "common expenses and common debt" and of new European taxes (for the period when the common debt will be reimbursed). As a matter of fact, without new instruments for a federal administration of economic policy, the monetary union itself would be at risk of breakdown (Accademia Nazionale dei Lincei, 2020; Marelli \& Signorelli, 2017).

\section{Italy. Response to the Crisis and Structural Problems}

Italy has been the first country hurt in Europe, on a time basis, by the pandemic. Hence, it was also the first one to adopt extraordinary measures to sustain the economy after the lockdown. Of course, the precarious situation of the economy and the limited fiscal space prevented an immediately sizeable fiscal manoeuvre (as Germany did). However, as time passed - becoming conscious of the damages created by the pandemic as well as aware of the new possible assistance provided by the EU - it increased the efforts, reaching an amount of fiscal expansion comparable to that of the most active countries (with an estimated initial support equal to $4 \%$ of GDP). Such measures were adopted through subsequent decrees from March to May, the most important ones being Decreto Cura Italia, Decreto Liquidità, Decreto Rilancio (followed by the more recent "Decreto Agosto").

They aimed at sustaining incomes of workers in lockdown activities through the "Cassa Integrazione Guadagni" (CIG) ${ }^{8}$, including the CIG "in deroga", i.e. for firms with less than five employees. A different relief was envisaged for autonomous (selfemployed) workers and small firms, including the temporary cancellation of local taxes (such as IRAP) or the postponement of other levies. The largest firms could get the support of "Cassa Depositi e Prestiti". If, in addition to new current expenditures and lower taxation, we consider also the state warranties on credits, the total financial resources mobilised reach $40 \%$ of GDP.

The subsequent decrees were complex and intricate (Decreto Rilancio includes more than 250 articles), they needed dozens of implementing decrees (most of them, yet to be approved). All of this explains, together with the notorious impediments created by the Italian bureaucratic system, because the implementation delay in Italy is double than in France and three times compared to the German one.

Even more worrying is that the adopted measures, although providing an unavoidable compensation for workers, families and firms damaged by the crisis, have been (so far) less useful to strengthen the recovery and long run growth 
perspectives. From this point of view, financial support should rather be directed to firms and sectors with greater resilience and innovation capacities.

$\square$ In any case, public accounts will suffer because of new expenditures, lower taxation and the big recession itself (that increases the relevant ratios). According to Government estimates in the "Economic and Financial Document" (MEF, 2020), the deficit/GDP ratio will reach this year $10.4 \%$ and debt/GDP ratio 155.7\%; OECD (2020) estimates are almost similar but only in the good scenario: $11.2 \%$ and $18.2 \%$; on the contrary, in the bad one they will reach $12.8 \%$ and $169.9 \%$ respectively. For 2021, OECD (2020) forecasts $6.8 \%$ and $9.7 \%$ (in the two scenarios) for deficit/GDP and $152.2 \%$ vs. $165.5 \%$ for debt/GDP.

It is true that at the moment "sustainability of public debt is not under discussion" (Bank of Italy, 2020); furthermore, it is important to recall that the private debt of families and firms is only $110 \%$ of GDP (50 points less than the Eurozone average). However, without a concrete support by the EU, future sustainability of the Italian public debt might be problematic. This explains the insistence of Italy in assuring a large proportion of resources available with the "Next Generation EU" Fund: they will consist in about $81 \mathrm{bn}$. euros of subsidies (grants) ${ }^{9}$ and $127 \mathrm{bn}$. of loans. A big question remains: to do what? A tentative answer is in the next sections.

\section{The urgency to sustain aggregate demand and relaunch investment}

The shock caused by the Covid-19 pandemic is the hugest one in almost a century. However, it was preceded by other deep crises in the last decade. As well known, since 2008 Europe was hit by a double recession: the "Great Recession" (2008-09) after the global financial crisis and a second one consequent to the Eurozone's crisis (2012-13), recessions followed by a feeble recovery, especially in the periphery of Europe. What is worrying is not only the low growth rate characterising the last decade, as compared for instance with the US economy, but also the high dispersion within the EU itself, with persisting and increasing imbalances. Germany and few other countries have little suffered because of the crises. The peripheral countries have been the most damaged especially Italy and Greece: in 2019, their real GDP was substantially below the 2007 level. On the other hand, some peripheral countries - Ireland, Spain, and Portugal - in the recent years (until 2019) recorded a stronger recovery, but the consolidation measures, including "internal devaluations" (i.e. compression of wages), caused in any case worsened social conditions.

The persistence in some countries of negative output gaps reveals that economic growth has suffered because of an insufficient aggregate demand, rather than structural limits, partly caused by the "austerity approach"10 followed by EU institution after the sovereign debt crisis (Marelli \& Signorelli, 2017). Within aggregate demand, the problem does not concern (as sometimes wrongly assumed) net exports ${ }^{11}$; in fact, it is internal demand that is lacking in Europe (Cappellin et al., 2018; Marelli, 2019). 
The situation has become grave after the pandemic. Both Italy and other European countries have adopted enormous fiscal stimuli to counteract the economic collapse induced by the shock. These were necessary to compensate the heavy losses incurred by individuals and firms in the recent period and some losses will be certainly suffered in the next months, at least in some sectors and activities.

In any case, well beyond the necessary reparations, some different strategies are needed to get a strong recovery and, for the future, a more sustainable growth. First of all, it is necessary to relaunch investment, both in Europe and even more in Italy. Figure 1 shows that total investment (gross fixed capital formation) decreased in the last decade, as percentage of GDP, in all countries, even in the United States. After a minimum reached in 2000-04 years, it partially recovered in 2015-18 in the latter country. Also in the EU, it returned to levels comparable to those exhibited in the '90s; on the contrary, in Italy the lowest level reached in 2015-18 (little more than 17 percent) is significantly lower than the figure exhibited in the early 2000s.

A similar situation is revealed by public investment (see Figure 2). It is true that also in the EU the incidence on GDP has recently been on the lower side, compared to previous decades; it also true that even in the US the mean value in the 2015-18 period is a very low figure (although it does not yet include the effects of the investment projects decided by the Trump administration). However, the Italian figure for the ratio (2.3\%) is about one third (i.e. 1 per cent of GDP) lower than the one exhibited a decade earlier. Therefore, it is worrying that in the difficult years, following the Great Recession, fiscal authorities did not provide a most needed counter-cyclical impulse.

Figure 1: United States, European Union \& Italy. Total Investment on GDP

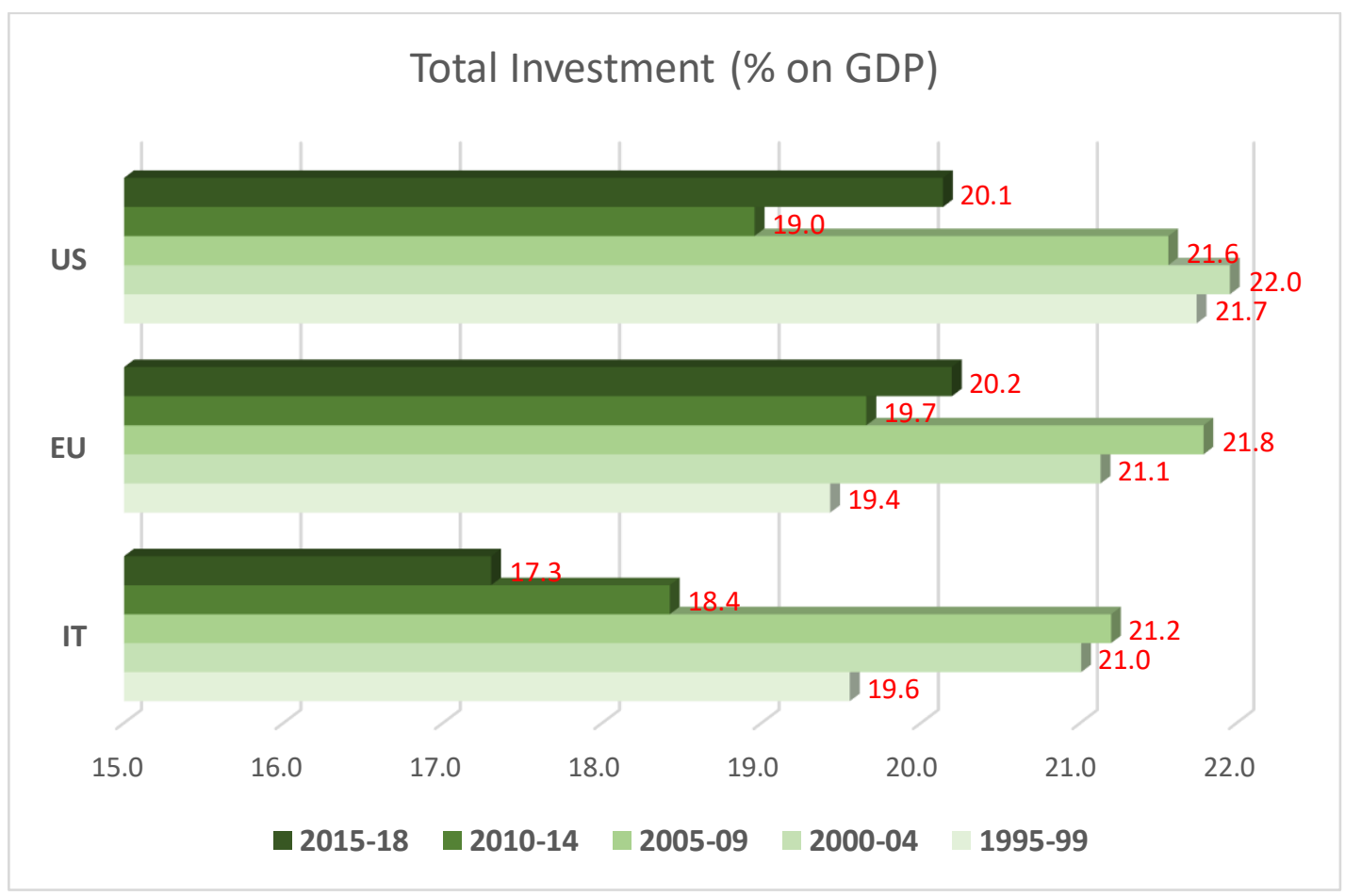

Source: Elaborations on OECD data. 
A complete reversal is urgently required (Marelli, 2019). Not only will a relaunch of investment guarantee a vital increase of aggregate demand and employment in the short run, but it will also allow an increase of productive capacity and efficiency in the long $\operatorname{run}^{12}$. A persistent higher growth in the long run will also improve the financial conditions.

$\square$ The Bank of Italy (2020) has estimated that a growth rate between $1 \%$ and $2 \%$ (so not far from the European average of the last decade) will be enough, if accompanied by an annual primary surplus of $1.5 \%$ (the average size realized in the recent years), to reduce the debt/GDP ratio by $2 \%$ each year. The decrease from a level of about $160 \%$, forecasted for the end of this year, will take a long time, but at least the risks of unsustainability will be excluded.

New investment should not necessarily be in big infrastructures, but could refer to many investment projects diffused over the territory; they should also refer to the Green Deal, the digital agenda and, of course, to the sectors penalised in the past by heavy cuts: health, education, R\&D. Such investments should also be consistent with new industrial and regional policies oriented to the new needs of the citizens (Brondoni et al., 2020), an element that can be crucial in the post-pandemic world.

In the case of Italy, a large investment plan financed by resources coming from the EU will be successful if it was able to overcome the notorious limits of the Italian administration. From this point of view, more checks from the EU institutions are welcome, especially if they will also help to reduce national faults such as tax evasion and corruption.

Figure 2: United States, European Union \& Italy. Public Investment on GDP

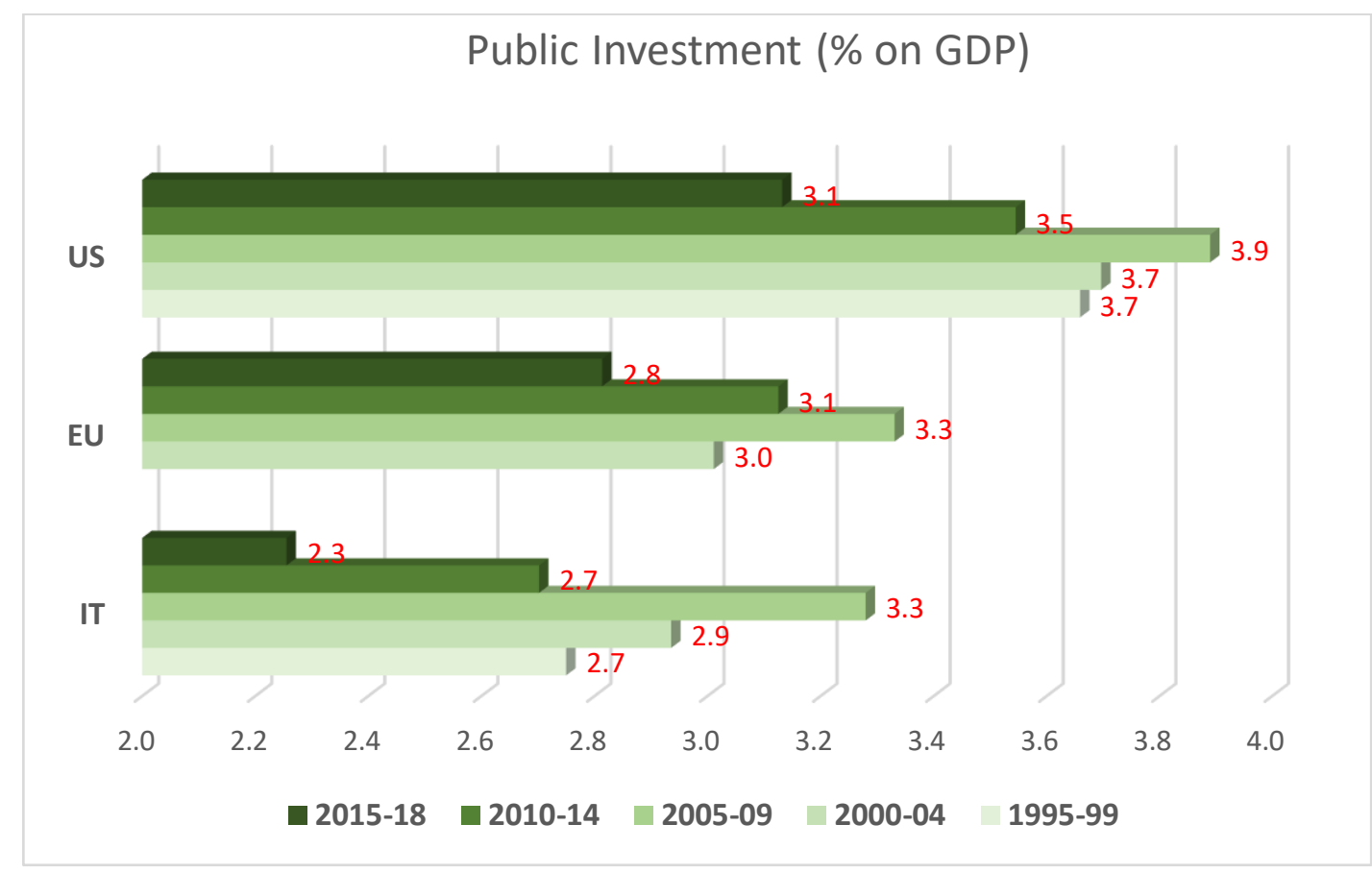

Source: Elaborations on OECD data. 
The guidelines for the "Next Generation Italia" plan released by the Italian Government (in September 2020) declare the key objective to double the growth rate of the economy: from $0.8 \%$ (annual average) of the last decade to $1.6 \%$ (corresponding to the EU average). An intermediate tool would be to raise the ratio of public investment to GDP from about $2 \%$ to $3 \%$. Six key "missions" have been identified to this end: digitalisation, innovation and competitiveness of the productive system; green revolution and ecological transition; infrastructures for mobility; education, training, research and culture; social, gender and territorial equity; health. The biggest drawback of this approach is that the individual projects, so far assembled from the proposals of the different Ministries, are more than 500. Although some selection criteria have been identified in the guidelines themselves (such as assessment of: the economic, environmental and social impact; the effects on potential output and employment; the financial costs and implementation times, etc.), it will not be easy to get sound priorities, avoiding pressures from various lobbies. Besides the risk of rejection by the EU authorities, it will be a shame, or even a crime, to waste an opportunity to radically transform the development of the Italian economy.

\section{The Need for a New, Sustainable and Inclusive Growth Model}

In addition to the economic sustainability of the growth strategy, pervasive dimensions of sustainability are crucial. It is a pervasive sentiment the necessity to "rethink the market economy", for example, moving from a deregulated to a regulated financial market, from short-termism to sustainable development, from polluting to green economy, from a price-driven to an innovation driven competition, from a globalised to a "glocalised" economy, from a mostly industry-based to a mostly knowledge-based economy, etc. (Lambin, 2014). We also know that efficiency is important in economic growth models, but while an efficient economy is concerned with just market innovation, an efficient society is concerned with "social innovation".

As for environmental sustainability, the pandemic has evidenced the delicate equilibrium between human actions and Mother Nature. Climate change is still a challenge, so the Green Deal investments are fundamental. It is welcome that the EU Commission has communicated that the Green Deal should account for $37 \%$ of total resources of the Next Generation EU Fund (while 20\% should be allocated to digitalisation).

Economic growth should also be socially sustainable. Even before the current crisis, poverty in Europe was shamefully high and the not succeeded reduction in poverty indices represents the major failure of the "Europe 2020" plan. The new crisis will further increase such indices as well as exacerbate social disruptions: extreme inequalities in income and wealth distribution, long-term unemployment (particularly distressing young people), etc. In some European countries more than one third of the young are unemployed or "Neet" (Not in employment, education or training), representing a "lost generation"13: this generation deserves nominal attention not only when deciding the names of the new funds...

For a country like Italy, it is fundamental to increase the job opportunities, not only among young people but also overall. Total employment rate (now 63\% for people 
20-64 years old) is ten points less than the EU average (73.2\%): the "Next Generation Italia" plan aims to eliminate this gap. Of course, it is also necessary to create "good" jobs, consistently with the adoption of new technologies ${ }^{14}$, and the improvement of human capital. Education would require much more consideration in the allocation of resources: Italy is once more the lagging country; for example, it exhibits one of the lowest shares of public expenses on GDP and the incidence of young people with tertiary degrees is just $27 \%$, compared to $40 \%$ for the EU average.

Therefore, we can better qualify the discourse of the previous section. The support of aggregate demand during huge recession periods - coming from Keynes's ideas are well-known, but himself always insisted that stimulus plans should aim also at a reduction of economic and social inequalities. Moreover, when sustaining aggregate demand, it is crucial the identification of sectors that are becoming more fundamental. In the current situation: health systems, digital services, etc. In the same vein, the most damaged sectors by the pandemic - tourism, transports, hotels, restaurants, cinemas, theatres and many other services in urban areas - need an equitable and efficient support by the State, regional and local authorities.

In any case, a new "model of development" is required to face the long run impact of the pandemic. What will be the new modes of productions, work methods, consumer habits, and lifestyles? Some examples will suffice: it is likely that more labour intensive employment will be needed, in social domains, such as: more teachers and smaller class sizes at all levels of education (pre-school, primary, secondary and higher); more health workers, also to shorten waiting lists for both diagnosis and treatment; more frequent low and zero emission public transport.

If it is impossible - and undesirable - to return to the old world, how will the "new normal" look like? The challenge to wise policy makers is open. It is just worth to stress that, while the guidelines of the "Next Generation Italia" plan fix right and proper goals (on growth rates, public investments, $R \& D$, etc.), the list of instruments to reach them is at the moment too long and blurred: the layout of clear priorities is the next challenge we have to face.

\section{Bibliography}

Accademia Nazionale dei Lincei (2020). Covid Crisis and Possible Shift for the European Union (in Italian). Covid-19 Commission.

Amato, M., Belloni, E., Falbo, P., \& Gobbi, L. (2020). A European Debt Agency as a Structural Response to the Crisis. 19 May.

http://www.primeeconomics.org/articles/a-european-debt-agency-as-a-structural-response-to-the-crisis

Baldwin, R., \& Weder di Mauro, B. (eds.) (2020). Economics in the Time of COVID-19, London, CEPR Press.

Bank of Italy (2020). The Governor's Concluding Remarks. Rome, 29 May.

Bénassy-Quéré, A., Boot, A., Fatás, A., Fratzscher, M., Fuest, C., Giavazzi, F., Marimon, R., Martin, P., Pisani-Ferry, J., Reichlin, L., Schoenmaker, D., Teles, P., \& Weder di Mauro, B. (2020). A Proposal for Covid Credit Line. VOX CEPR Policy Portal, 21 March.

Botta, A., Caverzasi, E., \& Russo A. (2020). Debt Monetization and EU Recovery Bonds. FEPS Covid Response Papers, April. 
Brondoni, S. M., Cappellin, R., \& Ciciotti, E. (2020). Ouverture de "The New European Industrial Strategy: Companies and Territories". Symphonya. Emerging Issues in Management (symphonya.unicusano.it), (2), 1-6.

http://dx.doi.org/10.4468/2020.2.01ouverture

Cappellin, R., Ciciotti, E., Baravelli, M., Barberio, R., Becchetti, L., Bellandi, M., Cortiana, F., Ferlaino, F., Foti, F., Garofoli, G., Marelli, E., Pescetti, C., \& Pilotti, L. (2018). The Response to the Needs of the Citizens and the Turnaround in European Policies: a Common Cultural and Political Platform for a Radical Change in European Economic Policies. Discussion Group "Growth, Investment and Territory", December.

http://economia.uniroma2.it/dmd/crescita-investimenti-e-territorio/

Caroleo, F. E., Demidova, O., Marelli, E., \& Signorelli, M. (eds.) (2018). Young People and the Labour Market: A Comparative Perspective. Abingdon: Routledge.

De Grauwe, P. (2020). The ECB Must Finance COVID-19 Deficits. Project Syndicate, 18 March.

Della Posta, P., \& Morroni, M. (and 18 first signatories) (2020). European Reanaissance Bonds, An Open Letter of European Economists to the Presidents of the EU Institutions and to the Heads of State and Government of the Member Countries", April.

Della Posta, P., Marelli, E., \& Signorelli, M. (2020). Market-Financed and Growth-Enhancing Investment Plan for the Euro Area. Metroeconomica, 71, 604-632.

http://dx.doi.org/10.1111/meca.12294

Discussion Group Growth, Investments and Territory (2020). WebForum “A New European Industrial Strategy and the European Recovery Program after the Covid-19 Crisis", 8 July.

EU Commission (2020). European Economic Forecast, Summer.

Galì, J. (2020). Helicopter Money: The Time is now. VOX CEPR Policy Portal, 17 March.

IMF, International Monetary Fund (2020). World Economic Outlook Update, June.

Lambin, J.-J. (2014). Rithinking the market economy. Symphonya. Emerging Issues in Management (symphonya.unimib.it). (2). 4-15.

http://dx.doi.org/10.4468/2014.2.02lambin

Marelli, E. (2019). How to Reach a Sustainable Growth in a Reformed EU. Paper presented at the Policy Forum: A New European Industrial Strategy Oriented to the Citizens and the Territory for a Reform towards Post-Neoliberal Economic Policies, European Economic and Social Committee, Bruxelles, 4 December.

Marelli, E., \& Signorelli, M. (2017). Europe and the Euro: Integration, Crisis and Policies. Palgrave MacMillan: London and New York.

Masciandaro, D. (2020). ECB Helicopter Money: Economic and Political Economy Arithmetic. Bocconi Working Paper n. 138, May.

MEF (Ministry of Economy and Finance) (2020). Economic and Financial Document, Section 1: Stability Program. Rome, 24 April.

OECD, Organisation for Economic Cooperation and Development (2020). Economic Outlook, June.

Panetta, F. (2021). Mind the Gap(s): Monetary Policy and the Way Out of the Pandemic, Speech of the Executive Member of the European Central Bank, 2 March 2021.

https://www.ecb.europa.eu/press/key/date/2021/html/ecb.sp210302 b618d33987.en.html

Valli, V. (2020). Coronavirus and the Art of not Learning from Other Countries' Experiences. Paper prepared for the $61^{\text {st }}$ Scientific Annual Meeting of "Società Italiana degli Economisti" (SIE).

\footnotetext{
Notes

${ }^{1}$ A first draft of this paper has been prepared for the WebForum of the Discussion Group (2020).

${ }^{2}$ Italy was the first country affected by the pandemic in Europe, but as of October $1^{\text {st }}$ a greater number of casualties is recorded in the United Kingdom (about 42000), followed by Italy (36000), France and Spain (32000 in both countries).
} 
Outside Europe, the highest number of dead is found in the United States (more than 210000) and Brazil (about 145000) (see https://www.worldometers.info/coronavirus/\#countries).

3 Worsened to a fall equal to $9 \%$ in the preliminary estimates prepared for the Nadef (Nota di aggiornamento del Documento di Economia e Finanza - Economic and Financial Document Update), that forecasts a rebound equal to $+6 \%$ in 2021 (estimates released at the end of September 2020).

${ }^{4}$ The QE, launched in 2015 by the former President Draghi, ended at the end of 2018; it restarted in November 2019 (following a decision taken by Draghi in the previous September, because the euro area's economy had already significantly decelerated during 2019).

${ }^{5}$ Masciandaro (2020) has shown that the effectiveness of this strategy depends on the existence of nominal rigidities and the working of redistributive effects.

${ }^{6}$ For example, the appeal by Della Posta, Morroni et al. (2020), regarding European Renaissance Bonds, has gained about 2000 adhesions in Europe.

${ }^{7}$ While the plan was supported by the Southern Europe countries and backed also by Germany and France, the strongest opposition came from the so-called "frugal four" (the Netherlands, Denmark, Sweden and Austria).

${ }^{8}$ Providing an income generally equivalent to $80 \%$ of previous wage or salary. In Italy the CIG workers are not considered as unemployed. This support, together with a norm that has suspended the dismissal of workers and the "discouraged worker" effect, explains why the unemployment rate reached in March 8.4\% (the lowest figure in a decade). A quick rise in the following months will probably lead to a $12 \%$ unemployment rate by the end of the year.

${ }^{9}$ Of which 63.8 bn. through the Recovery and Resilience Facility and the remaining part by means of other instruments (such as ReactEU).

${ }^{10}$ Austerity has been "self-defeating" (as argued by P. Krugman), because the efforts to reduce public deficits have dampened economic growth, thus making more difficult, in some cases even impossible, the reduction of the debt/GDP ratios.

${ }^{11}$ Apart from the German extraordinary performance in exports (with a current account surplus well above the ceiling of $6 \%$ of GDP, the benchmark indicated by the EU macroeconomic imbalance procedure), even the peripheral countries of the Eurozone have exhibited in the recent years a trade surplus.

12 Della Posta, Marelli \& Signorelli (2020) emphasize a further aspect: an investment plan, realized and financed at the European level, by raising growth capabilities, will reduce the interest rate on existing sovereign debts.

${ }^{13}$ For a comparative analysis of the situation of young people in the labour market, in Italy and in other countries, see Caroleo et al. (2018).

14 The ratio between R\&D and GDP should increase from $1.3 \%$ to $2.1 \%$, according to "Next Generation Italia" plan. 